https://doi.org/10.1590/198053145513

\title{
CHALLENGES FOR THE DESIGN OF NEW PEDAGOGIES BASED ON MOBILE TECHNOLOGIES
}

\author{
Eduardo Rodríguez Zidán' \\ Carmen Yot " \\ Claudia Cabrera"l! \\ Juan Pablo Zorrilla Salgador Iv \\ Javier Grilli Silvav \\ Translated by Marina Melaniv
}

\begin{abstract}
Despite the fact that investment in technology has increased in Latin America, little is yet known about the integration of mobile devices in educational practices. The objective of this article is to analyse the access, perception of usefulness and frequency of use of the laptops provided free of charge by Plan Ceibal from Uruguay in the pre-professional practices of student teachers. A mixed method was used for the investigation, which includes a survey to 385 students and 15 in-depth interviews. Results show a limited pedagogical use of mobile devices as well as important challenges for emergent pedagogies. Most of the participants incorporate the mobile devices in traditional teaching approaches.
\end{abstract}

\section{LAPTOPS • DIGITAL TECHNOLOGY • TEACHER TRAINING • TEACHING PRACTICE}

\section{DESAFIOS PARA EL DISEÑO DE NUEVAS PEDAGOGÍAS BASADAS EN TECNOLOGÍAS MÓVILES}

\section{Resumen}

A pesar del incremento de la inversión en tecnología en Latinoamérica todavía se conoce poco acerca de la integración de dispositivos móviles en las prácticas educativas. El objetivo de este artículo es analizar el acceso, la percepción de utilidad y la frecuencia de uso de los ordenadores portátiles entregados gratuitamente por el Plan Ceibal de Uruguay en la práctica pre-profesional de los estudiantes de profesorado. Se aplicó un método mixto de investigación que incluye una encuesta a 385 estudiantes y 15 entrevistas en profundidad. Los resultados revelan un escaso aprovechamiento pedagógico de los dispositivos móviles e importantes desafíos para las pedagogías emergentes. La mayoría de los participantes incorporan los dispositivos móviles en enfoques tradicionales de enseñanza.

\section{ORDENADORES PORTÁTILES • TECNOLOGÍA DIGITAL • FORMACIÓN DE PROFESORES • PRÁCTICA DE ENSEÑANZA}

\footnotetext{
I Universidad ORT Uruguay, Montevideo, Uruguay; http://orcid.org/0000-0002-6437-578x; rodriguez_ce@ort.edu.uy

II Universidad de Sevilla, Sevilla, España; http://orcid.org/0000-0001-9447-8993; carmenyot@us.es

III Universidad ORT Uruguay, Montevideo, Uruguay; http://orcid.org/Oo00-0002-1419-6791; claudiaanahi@gmail.com

IV Universidad ORT Uruguay, Montevideo, Uruguay; http://orcid.org/0000-0001-9786-6457; juanpab/ozorrilla@gmail.com

V Ce.R.P del Litoral, CFE, ANEP, Salto, Uruguay; http://orcid.org/0000-0002-6690-1659; javigrill@hotmail.com

VI Universidad ORT Uruguay, Montevideo, Uruguay; https://orcid.org/0000-0002-4533-4026; marinamelani.r@gmail.com. 


\section{DÉFIS POUR L'ÉLABORATION DE NOUVELLES PÉDAGOGIES BASÉES SUR LES TECHNOLOGIES DIGITALES}

\section{Résumé}

Malgré l'augmentation des investissements en technologie en Amérique latine, il y a encore peu de connaissances à propos de l'intégration des dispositifs mobiles dans les pratiques éducatives. Le but de cet article est d'analyser l'accès, la perception de l'utilité, la fréquence de l'utilisation dans la pratique pre professionnelle des ordinateurs portables, distribués gratuitement aux étudiants de pédagogie en Uruguay, dans le cadre du plan Ceibal. Une méthodologie mixte de recherche comprenant une enquête auprès de 385 étudiants et 15 entretiens en profondeur a été adoptée. Les résultats révèlent que l'utilisation pédagogique des ordinateurs portables reste très insuffisante posant d'importants défis pour les nouvelles pédagogies. Pour la plupart des participants, en effet, l'utilisation des ordinateurs portables s'encadre dans des approches pédagogiques traditionnelles.

\section{ORDINATEURS PORTABLES - TECHNOLOGIE NUMÉRIQUE • FORMATION DES ENSEIGNANTS • PRATIQUE PÉDAGOGIQUE}

\section{DESAFIOS PARA O DESENHO DE NOVAS PEDAGOGIAS BASEADAS EM TECNOLOGIAS MÓVEIS}

\section{Resumo}

Apesar do aumento do investimento em tecnologia na América Latina, ainda se conhece pouco sobre a integração de dispositivos móveis nas práticas educacionais. 0 objetivo deste artigo é analisar o acesso, a percepção de utilidade e a frequência de uso dos laptops entregues gratuitamente pelo Plano Ceibal do Uruguai na prática pré-profissional dos alunos de pedagogia. Foi aplicado um método de pesquisa misto que inclui uma enquete a 385 alunos e 15 entrevistas em profundidade. Os resultados revelam um escasso aproveitamento pedagógico dos laptops e importantes desafios para as pedagogias emergentes. A maioria dos participantes incorpora os laptops a abordagens tradicionais de ensino. 
and the Caribbean have strongly encouraged ICT policies that contribute to the universalisation of internet by investing in technological infrastructures in schools (UNESCO, 2016a). Recently, evidence from diverse international reports and academic studies shows the incorporation of multiple initiatives and national plans based on the use of technologies and, specifically the development of educational programs based on mobile technologies in education (HINOSTROZA, 2017; UNESCO, 2016b, 2017).

In the case of Uruguay, the massive delivery of laptops has positioned the country in a privileged position regarding the management of digital technologies. Nevertheless, little is yet known about how technology is being integrated in the educational practices and the way in which this is changing traditional pedagogies for emerging ones (ADELL; CASTAÑEDA, 2012). In relation to this, a recent report from UNESCO (2016a, p. 113) indicates that "ICT policies in education still need to consider the teacher training degree in their agenda."

The present article is part of the joint research carried out by ORT University (Uruguay) and the University of Seville (Spain) $)^{1}$ with the main purpose 
of contributing knowledge on the experience of the incorporation of digital and mobile technologies in the teacher training degrees of Uruguay. All this in an international context where new pedagogies for learning supported by multiple digital resources are arising (FERGUSON; BUCKINGHAM, 2012; FULLAN; QUINN, 2017; MCKINSEY, 2017).

In this general framework, we propose exploring the students and teachers' use and perceptions of the m-learning technology in the teacher training degree, based on the assumption that this technology integrates both formal and informal learning, regardless of space and time (DE-MARCOS et al., 2010). We consider m-learning to be a way of learning that operates through the use of devices such as the laptop or the smartphone. In this process, multiple factors come into play such as contextual ones (training of trainers, perception of change), technological ones related to the device (hardware, interface, technological infrastructure) and factors related to the design of the learning environment or new pedagogy (SALEH; BHAT, 2015).

The present study aims to explore whether the fact that student teachers have access to the laptop ensures its use to facilitate their own learning and its integration in their own practices as future teachers. The study will focus on the frequency of use of the laptops and on what they are used for, in the different subjects of the teacher training degree according to the guidance provided by the teachers. It will be explained the impact that such level and type of use has on how the laptops are used in the pre-professional practices, in institutions of secondary education. It is because of this that the knowledge about the use experiences of laptops for learning and for the teachers' professional development in the first teaching experiences is enhanced.

\section{THEORETICAL FRAMEWORK}

In the $21^{\text {st }}$ century, the training of teachers in digital technologies still poses a challenge both at the teacher training level and in terms of their professional development (CASTANEEDA; ESTEVE; ADELL, 2018). It is vital to empower teachers as driving forces of change and to propose support strategies that aim at achieving a significant ownership of digital technologies in teaching practices.

The accomplishment of the aforementioned goals requires the use of ICT for teaching and learning to be an explicit part of the training schemes, and this incorporation should involve different strategies for pedagogical use. Another key component for the change to take place are the trainers of trainers, since it is essential for them to have digital competencies in order to train their students (ASLAN; ZHU, 2015; KALONDE; MOUSA, 2016). Initiatives are being implemented in multiple international contexts, together with strategies to facilitate the integration of technologies in the teacher training degree to achieve the longawaited transference (BAKIR, 2016).

Ceibal is taking actions that go in line with the idea of strengthening teacher training processes and promoting the pedagogical use of technologies 
(CEIBAL, 2017). The same reality is found in international reports. The investigation report of UNESCO (2016a, p. 60) mentions that, even though training and support strategies directly for teachers have been deployed, these still have a limited scope and the effort is insufficient in order to "leave established changes in the teaching practices".

In summary, changes in the teaching practices to favour better learning processes have become a recurrent topic in educational research, even more when it regards practices that include digital technologies in the classroom (GALPERING, 2017).

This research proposes to identify and characterise best practices that include ICT, drawn from the perceptions and accounts of the teachers and students' experiences regarding the inclusion of technology in the teacher training degree.

The concept of "best practices" in ICT varies and includes multiple dimensions regarding the use of technology in teaching. For Alexander (1997), a key aspect for a best practice is that teachers, in a reflexive way, elaborate and contextualise the pedagogical proposal.

Regarding best practices in e-learning, a study carried out by Cabero (2010) identified that these are characterised by the teachers' technical and teaching competencies, together with an intensive use of online material and a studentcentred learning approach.

On a complementary perspective to the aforementioned, best practices with technology within education are defined as "educational experiences and teaching practices that integrate digital resources with free software and communication networks to create new content and school organization systems, to promote other type of educational activities and to encourage collaborative working strategies" (DE PABLOS; JIMÉNEZ, 2007, p. 26). In particular, this definition goes in line with the theoretical guidelines and the technological model encouraged in Uruguay, given that the laptops delivered to students and teachers allow the access to content and resources based on free software through an institutional platform called CREA2.

The conceptualisation of a best practice with ICT inclusion means, therefore, the creation of new educational content, as well as changes in the ways knowledge is built.

There are studies that prove that teachers who have an available laptop change their attitude towards a more positive one regarding technologies, in comparison to those who do not have one (SIPILÄ, 2010). Particularly, future teachers that have these devices increase their level of ability with technology (DONOVAN; GREEN; HANSEN, 2011).

Certain authors such as Cobo (2016, p. 92) state that technology must not be used as mere devices to replicate traditional practices, but that “disruption [...] 
lies in using technology more strategically in order to create new ways of generating value" 2 .

The revision of a significant number of experiences from different countries reveals that what prevails is the teachers' technological knowledge over the techno-pedagogical one regarding content or the emergence of new pedagogies different from the traditional ones (HUTCHISON; REINKING, 2011; RODRIGUEZ et al., 2017). Teachers themselves are one of the fundamental variables and become essential to ensure quality in the teaching of new content and in the sensible pedagogical use of digital resources made available for students and teachers (VAILLANT; RODRIGUEZ; BERNASCONI, 2017).

\section{METHODOLOGY}

The study is supported by a mixed research method in education due to the intention of articulating and combining quantitative and qualitative data with the purpose of achieving a deeper and multidimensional analysis. Including strategies from both approaches allowed, also, a methodological triangulation (DENZIN; LINCON, 2005) to increase the validity of the findings. The methodological design created for this study identifies with the embedded design with priority in the qualitative data, in keeping with Creswell and Plano (2007).

The development of the method was done in two phases. In the first one, the adopted quantitative perspective enabled the correlational descriptive nonexperimental cross-sectional analysis, through the distribution of a digital survey. The second phase was based on the qualitative approach that sought to reveal the perspectives of the subjects involved in the study through the application of semi-structured interviews to a sample that consisted of third and fourth year student teachers, didactics teachers and, trainers of trainers.

Different samples were selected in the two phases, considering the type and nature of the data to be collected depending on the chosen approach.

\section{SAMPLE 1}

In the first place, for the quantitative part of the study, the sample of students was purposive non-probabilistic and stratified by their year of study (third, fourth or graduated at the moment of the data collection in the year 2017). The main criteria for the selection of the individuals belonging to the sample was having a laptop delivered to the students free of charge as part of the Plan Ceibal program, in Uruguay. ${ }^{3}$

The analysis of secondary data required by the educational authorities allowed us to identify an initial sampling frame of 2250 student teachers that gathered the previously defined inclusion criteria. An invitation to complete the

2 In original: "la disrupción [...] está en hacer un uso más estratégico de la tecnología para crear nuevas formas de generar valor".

3 Laptops are delivered free of charge to student teachers and primary student teachers at the beginning of their third year, when the pre-professional practice phase begins. 
survey was sent to each of them via email. The sending and reception of the online forms were done between July and October of 2017, using the platform LimeSurvey. The sending of the forms was done successively, reinforcing communication and ensuring anonymity with the purpose of increasing the levels of validity and trust of the students. The response rate was 17\%, an acceptable level based on studies with similar methodologies (HEERWEGH; LOOSVELDT, 2008).

The profile of the participants' sample of the study is shown in Table 1. The final sample ended up composed of 385 student teachers, 73\% being female students and 27\% male ones, with an age average of 36 years old (SD 9.2, Min 21 and Max 65). 44\% of them studies science (experimental science, natural science or exact science) whereas the rest studies a teacher training degree related to art or humanities. With regard to the modality of the study, $67.3 \%$ of the students are enrolled in the face-to-face modality, and the rest take part in a hybrid training model or blended learning, with an important component of virtual education.

TABLE 1

VARIABLES THAT CHARACTERISE THE STUDY POPULATION

\begin{tabular}{|c|c|c|}
\hline VARIABLE & FREQUENCY & PERCENTAGE \\
\hline Gender & & \\
\hline Feminine & 281 & $73 \%$ \\
\hline Masculine & 104 & $27 \%$ \\
\hline Modality & & \\
\hline Blended learning & 126 & $32,7 \%$ \\
\hline Face-to-face & 259 & $67,3 \%$ \\
\hline Speciality & & \\
\hline Humanities & 202 & $52,5 \%$ \\
\hline Science & 170 & $44,2 \%$ \\
\hline Number of observations & 385 & - \\
\hline
\end{tabular}

Source: Authors' elaboration.

\section{SAMPLE 2}

Regarding the participants' sample for the qualitative approach, a theoretical and intentional sampling was applied, following Maxwell's (1996) recommendations about the sampling procedure that seeks maximum stratification of differences. 15 in-depth interviews were carried out to students and teachers of the different segments or relevant strata for the investigation (face-to-face or b-learning modalities, training degree speciality, role as trainer of trainers). Table 2 presents the profile of the theoretical sample selected for the study. 
TABLE 2

POPULATION OF THE INVESTIGATION TO WHICH INTERVIEWS WHERE APPLIED

\begin{tabular}{|c|c|c|c|c|}
\hline ACTORS & $\begin{array}{l}\text { MODALITY OF } \\
\text { THE COURSE }\end{array}$ & SPECIALITIES OR POSITION & CODES & $\begin{array}{l}\text { NUMBER OF } \\
\text { INTERVIEWS }\end{array}$ \\
\hline Manager - Informatics & -------- & $\begin{array}{l}\text { Member of the department of } \\
\text { digital technologies at the CFE* }\end{array}$ & GTT & \multirow{3}{*}{3} \\
\hline \multirow{2}{*}{ Manager - coordinator** } & \multirow{2}{*}{-------- } & Natural Science & GCN & \\
\hline & & Social Science & GCS & \\
\hline \multirow{8}{*}{ Didactics teachers } & \multirow{4}{*}{ Face-to-face } & History & PDHP & \multirow{8}{*}{8} \\
\hline & & Sociology & PDSP & \\
\hline & & Chemistry & PDQP & \\
\hline & & Biology & PDBP & \\
\hline & \multirow{4}{*}{ Blended Learning } & Chemistry & PDQSP & \\
\hline & & Mathematics & PDMSP & \\
\hline & & Biology & PDBSP & \\
\hline & & Drawing & GTT & \\
\hline \multirow{4}{*}{ Student teachers } & \multirow{2}{*}{ Face-to-face } & Chemistry & GCN & \multirow{4}{*}{4} \\
\hline & & History & GCS & \\
\hline & \multirow{2}{*}{ Blended Learning } & Mathematics & PDHP & \\
\hline & & Biology & PDSP & \\
\hline
\end{tabular}

*Commission designed by the Education Training Council, in charge of the promotion of the use of digital technologies in the training of teachers in Uruguay.

${ }^{* *}$ Academic coordinators of the respective training degree areas.

Source: Authors' elaboration.

For the collection of the qualitative data, the survey Survey of Mobile device use during was adapted and validated as an instrument (WITECKI; NONNENCKE, 2015). The students' perceptions about the utility of laptops are analysed through a descriptive study of selected variables followed by a contrast of hypothesis through a correlational analysis technique between factors. The advantages of using online forms are stated by international studies (HOLMBERG; LORENC; WERNER, 2010; DÍAZ DE RADA, 2012) and refer to the possibility of reaching the selected population directly. Furthermore, this is done at the lowest cost of hiring surveyors; it allows the introduction of audio-visual elements and other stimuli in the instrument design and the rapid access to populations that are in geographically dispersed locations. The online self-administrated survey through internet, due to its modality, offers a greater assurance of anonymity and lower acquiescence and social desirability of the answers (HEERWEGH; LOOSVELDT, 2008).

The elaborated digital questionnaire included socio-academic variables related to the profile of the students, characterisation of the type of access to technology, analysis using Likert scales referred to the use of the laptop in the teacher training degree (three types of scenarios: educational centre, preprofessional practices and at home). It also included open questions to know the self-perception of future teachers about their experiences of the pedagogical use of the device in their training process. 
TABLE 3

DIMENSIONS, VARIABLES AND TYPES OF QUESTIONS OF THE APPLIED INSTRUMENT

\begin{tabular}{|c|c|c|c|}
\hline DIMENSION & DESCRIPTION OF THE VARIABLES & ITEMS & $\begin{array}{l}\text { TYPES OF } \\
\text { QUESTIONS }\end{array}$ \\
\hline Sociodemographic & Gender and Age & $1-2$ y 6 & $\begin{array}{l}\text { Polytomous and } \\
\text { quantitative }\end{array}$ \\
\hline Academic & $\begin{array}{l}\text { Entry year, current level of study, } \\
\text { specialty and modality of the } \\
\text { course. }\end{array}$ & $3-5$ y $7-8$ & $\begin{array}{l}\text { Dichotomous, } \\
\text { polytomous and } \\
\text { multiple answers. }\end{array}$ \\
\hline ICT Access & $\begin{array}{l}\text { Access to different type of digital } \\
\text { resources, Access to Internet, Type } \\
\text { of Connection and Support. }\end{array}$ & $9-17$ & Likert Scale \\
\hline $\begin{array}{l}\text { Use of laptops in the } \\
\text { educational centre and in the } \\
\text { practice centre. }\end{array}$ & $\begin{array}{l}\text { Access and frequency of use of } \\
\text { laptops in the educational centre } \\
\text { and in the pre-professional practice } \\
\text { centre. }\end{array}$ & $18-26$ y 29 & Likert Scale \\
\hline $\begin{array}{l}\text { Use of laptops outside the } \\
\text { educational centre. }\end{array}$ & $\begin{array}{l}\text { Access and frequency of use of } \\
\text { laptops outside the educational } \\
\text { centre and the pre-professional } \\
\text { practice. }\end{array}$ & $\begin{array}{c}30-37 y \\
40-42\end{array}$ & Likert Scale \\
\hline $\begin{array}{l}\text { Self-perception of the } \\
\text { educational change as of the } \\
\text { use of laptops. }\end{array}$ & $\begin{array}{l}\text { Self-perception of the educational } \\
\text { change based on mobile devices } \\
\text { and best practice accounts of } \\
\text { pedagogical use of mobile devices. }\end{array}$ & $\begin{array}{l}27-28 \text { y } \\
38-39 y \\
43-45\end{array}$ & Open Questions \\
\hline
\end{tabular}

Source: Authors' elaboration.

The results regarding the degree of reliability and internal consistency of the used scales are presented in Table 4. Data account for the three considered scales and specify that the items of the scales are strongly correlated. The observed values confirm the internal consistency and high levels of reliability that enable the confirmatory data study (JISU; DELORME; REID, 2006).

\section{TABLE 4}

\section{LEVELS OF RELIABILITY OF THE MEASUREMENT SCALES USED}

\begin{tabular}{|l|c|c|c|}
\hline \multicolumn{1}{|c|}{ SCALES } & N & $\begin{array}{c}\text { CRONBACH'S } \\
\text { ALPHA }\end{array}$ & DECISION* \\
\hline $\begin{array}{l}\text { Scale to measure the frequency of use of laptops in the } \\
\text { classroom of the educational centre. }\end{array}$ & 299 & 0.863 & Very Good \\
\hline $\begin{array}{l}\text { Scale to measure type of activities performed with the } \\
\text { laptop in the educational centre. }\end{array}$ & 296 & 0.834 & Very Good \\
\hline $\begin{array}{l}\text { Scale to measure type of activities performed with the } \\
\text { laptop outside the educational centre. }\end{array}$ & 292 & 0.929 & Excellent \\
\hline
\end{tabular}

*The interpretative criterion suggested by Jisu, Delorme and Reid (2006) is applied, who recommends that for confirmatory studies the value must be higher to the value of 0.80 .

Source: Authors' elaboration.

With regard to the qualitative approach, a guide for semi-structured interviews was elaborated and applied to the individuals that conformed the sample chosen according to the previously defined criteria. The script was validated by didactics experts and by researchers in educational technologies. The meetings to carry out the data collection took place in the educational centre itself, but outside the classrooms. The average length of the interviews was 40 minutes. 
The main structure of the script for the interview, as well as the theoretical references used for the design of the aprioristic categories are presented in Table 5.

TABLE 5

SCRIPT FOR THE INTERVIEW, DIMENSIONS AND CONCEPTUAL REFERENCES

\begin{tabular}{|c|c|c|c|}
\hline $\begin{array}{l}\text { DIMENSION OF } \\
\text { THE ANALYSIS }\end{array}$ & CATEGORIES & SCRIPT (QUESTIONS) & $\begin{array}{l}\text { CONCEPTUAL } \\
\text { REFERENCES }\end{array}$ \\
\hline \multirow{2}{*}{$\begin{array}{l}\text { The use of } \\
\text { laptops in } \\
\text { teaching } \\
\text { practices }\end{array}$} & $\begin{array}{l}\text { In the teacher } \\
\text { training degree }\end{array}$ & \multirow{2}{*}{$\begin{array}{l}\text { Question for Didactics teachers: } \\
\text { Do you observe differences between } \\
\text { the use of mobile devices in the classes } \\
\text { from the teacher training degree and } \\
\text { the teaching practices? }\end{array}$} & \multirow{2}{*}{$\begin{array}{l}\text { Castañeda, Esteve and } \\
\text { Adell (2018); Cobo } \\
\text { (2016); Aslan and Zhu } \\
\text { (2015); Kalonde and } \\
\text { Mousa (2016); Aesaert, } \\
\text { Tondeur and Siddiq } \\
\text { (2018) }\end{array}$} \\
\hline & $\begin{array}{l}\text { In the teaching } \\
\text { practices in } \\
\text { secondary } \\
\text { education }\end{array}$ & & \\
\hline \multirow{2}{*}{$\begin{array}{l}\text { Guidance for the } \\
\text { pedagogical use } \\
\text { of laptops }\end{array}$} & $\begin{array}{l}\text { Offered by the } \\
\text { didactics teachers }\end{array}$ & \multirow[b]{2}{*}{$\begin{array}{l}\text { Question for managers: Do you know } \\
\text { experiences in which didactics teachers } \\
\text { guide future educators regarding how } \\
\text { to use the ceibalitas to favour learning? } \\
\text { Could you narrate some that you } \\
\text { consider valuable and explain why you } \\
\text { consider it so? } \\
\text { Question for Didactics teachers: } \\
\text { Do you believe it is necessary to offer } \\
\text { guidance to future educators regarding } \\
\text { how to use ceibalitas to favour } \\
\text { learning? } \\
\text { Question for students: } \\
\text { Do you consider to have received } \\
\text { didactic guidance on how to use } \\
\text { ceibalitas to favour learning? } \\
\text { In case the answer is yes, have you } \\
\text { implemented in such experiences? } \\
\text { Could you narrate any that you } \\
\text { consider valuable and explain why you } \\
\text { consider it so? }\end{array}$} & \multirow[b]{2}{*}{$\begin{array}{l}\text { Castañeda, Esteve and } \\
\text { Adell (2018) } \\
\text { Aesaert, Tondeur and } \\
\text { Siddiq (2018) } \\
\text { Vaillant (2013) } \\
\text { Cabero and Romero } \\
\text { (2010) }\end{array}$} \\
\hline & $\begin{array}{l}\text { Asked by the } \\
\text { future teachers }\end{array}$ & & \\
\hline \multicolumn{2}{|c|}{$\begin{array}{l}\text { Activities implemented with the } \\
\text { laptops }\end{array}$} & $\begin{array}{l}\text { Question for Didactics teachers: } \\
\text { Have your students implemented } \\
\text { teaching experiences that involve the } \\
\text { mediation with mobile devices? } \\
\text { In case the answer is yes, narrate some } \\
\text { experience that you consider valuable } \\
\text { and explain why you consider it so. } \\
\text { What type of activities linked to mobile } \\
\text { devices do your student teachers } \\
\text { propose in their teaching practices? } \\
\text { Question for students: do you propose } \\
\text { activities to your students that involve } \\
\text { mobile devices? What type of activities } \\
\text { do you propose? }\end{array}$ & $\begin{array}{l}\text { Marcelo, Yot and } \\
\text { Mayor (2011) } \\
\text { Fullan and Quinn } \\
\text { (2017) }\end{array}$ \\
\hline \multirow{2}{*}{$\begin{array}{l}\text { Best practices } \\
\text { that include } \\
\text { laptops }\end{array}$} & $\begin{array}{l}\text { In the teacher } \\
\text { training degree }\end{array}$ & \multirow{2}{*}{$\begin{array}{l}\text { Question for Didactics teachers and } \\
\text { students: to your understanding, what } \\
\text { characteristics must have best practices } \\
\text { that involve mobile devices to favour } \\
\text { learning have? }\end{array}$} & \multirow{2}{*}{$\begin{array}{l}\text { De Pablos and } \\
\text { Jiménez (2007) } \\
\text { Maggio (2014) }\end{array}$} \\
\hline & $\begin{array}{l}\text { In the teaching } \\
\text { practice in } \\
\text { secondary } \\
\text { education }\end{array}$ & & \\
\hline
\end{tabular}

Source: Authors' elaboration.

The analysis of the quantitative data was done with the help of the SPSS software, version 25. In the first place, descriptive analyses were done (distribution of relative and absolute frequencies, Median, Standard deviation, 
Minimum, Maximum, indicators construction). Secondly, contrast of hypotheses was done to study the correlation among diverse factors considered relevant for the study. The analysis of the comparison variables was done using the contrast statistical Chi-square test () for bivariate hypothesis. For that purpose, data were organised in contingency tables. The probability values have been interpreted as statistically significant being them.

Given that the main objective is to analyse how access, perception, and use of laptops influence the pre-professional practices of student teachers within Plan Ceibal in Uruguay, the following research hypotheses are posed:

1. Access to the laptop delivered by Ceibal favours the use of the device in the pre-professional practices of the students.

2. The perceptions that students have about how their way of learning has changed the use of laptops influences positively in their predisposition of using them in their pre-professional practices.

3. The use of laptops in pre-professional practices is higher due to the Didactics' teachers' requests to students for them to include laptops in their pedagogical proposals.

Finally, for the qualitative approach, interpretative and explicative categories were elaborated for the analysis of the meanings assigned by the participants of the study (MILES; HUBERMAN, 1984). Qualitative data were analysed through procedures proposed by the constant comparative method (GLASER; STRAUSS, 1967; STRAUSS; CORBIN; ZIMMERMAN, 2002). Such analysis implied starting with the information obtained in the interviews, identifying significant text segments or valuable testimonies to understand ICT practices. After successive readings performed by the research team, the second step was to build data in an increasing abstraction process that included both the descriptive and the relational, as well as the analytic interpretation using deductive and emerging categories. The systematisation, codification and construction of interpretative frameworks process allowed the construction of emerging categories supported by the Atlas Ti 7.5 software.

\section{RESULTS}

Results are organised in five main blocks. In the first place, the degree of access to technologies and devices is described. Furthermore, it is analysed the relation between access to laptops and use of technologies in different contexts of the teacher training degree.

Secondly, an analysis of the factors that influence the future teachers' decision of incorporating the mobile device in their practices is presented. Next, there is an examination of the guidance - given by the trainer of trainees or requested by the students - for the inclusion of mobile technologies in their preprofessional practices.

Finally, and closely connected to the aforementioned, the activities supported by technologies proposed by students and teachers are analysed. This 
last analysis incorporates evidence about the perceptions of what a best practice in ICT means.

The students that participated in the study have access to a wide range of digital resources and to internet, both in the formal environment where they work and in their homes.

\section{TABLE 6}

ACCESS TO DIGITAL TECHNOLOGIES AND MOBILE DEVICES (\%)

\begin{tabular}{|c|c|c|}
\hline ITEM & YES & NO \\
\hline Personal laptop & 90.4 & 9.6 \\
\hline Laptop delivered by Plan Ceibal & 83.2 & 16.8 \\
\hline Internet connection in the educational centre. & 87.3 & 12.7 \\
\hline Internet connection in the highschool or training centre for pre-professional practices. & 77.0 & 23.0 \\
\hline Internet connection at home. & 93.5 & 6.5 \\
\hline Mobile Internet connection (monthly contract) & 79.3 & 20.7 \\
\hline Pay as you go Internet connection (prepaid) & 19.6 & 81.4 \\
\hline Standard Mobile Phone & 39.8 & 61,2 \\
\hline Smartphone & 72.1 & 27.9 \\
\hline Uses laptops in the Educational Centre. & 49.8 & 50.2 \\
\hline Does the given laptop work correctly? & 55.0 & 45.0 \\
\hline Do you consider that the use of digital technologies has improved your way of learning? & 85.0 & 15.0 \\
\hline Do you consider that the use of laptops has improved your way of learning? & 54.0 & 46.0 \\
\hline
\end{tabular}

Source: Authors' elaboration

The data collected in Table 6 allow us to draw three preliminary conclusions. In the first place, referred to the access. Students, besides receiving laptops delivered by the authorities, already have personal computers, they access Internet (more frequently at home, followed by the educational centre and last by the training centre where they perform their pre-professional teaching practices). Secondly, data confirm that a high proportion (45\%) of the laptops delivered to the students does not work correctly at the moment of the study. Last, the findings indicate that value is placed on the impact of the use of digital technologies in general terms rather than on the device itself.

Despite student teachers having ease of access to a laptop, evidence shows that, from a quantitative and qualitative analysis, these are seldom used, neither for subjects from the training degree nor in their teaching practices. 


\begin{tabular}{|l|c|c|c|c|c|}
\hline \multicolumn{1}{|c|}{ ITEM } & $\begin{array}{c}\text { ALMOST } \\
\text { NEVER OR } \\
\text { NEVER }\end{array}$ & $\begin{array}{c}\text { AT LEAST } \\
\text { ONCE A } \\
\text { MONTH }\end{array}$ & $\begin{array}{c}\text { AT LEAST } \\
\text { ONCE A } \\
\text { WEEK }\end{array}$ & $\begin{array}{c}\text { IN EVERY } \\
\text { CLASS OR } \\
\text { ALMOST } \\
\text { EVERY } \\
\text { CLASS }\end{array}$ & INDICATOR \\
\hline $\begin{array}{l}\text { Classrooms used for } \\
\text { subjects from the teacher } \\
\text { training degree. }\end{array}$ & 42.5 & 11.6 & 21.3 & 24.6 & 45.9 \\
\hline $\begin{array}{l}\text { Classrooms belonging to } \\
\text { NFPC* }\end{array}$ & 50.7 & 12.0 & 24.0 & 13.3 & 37.3 \\
\hline $\begin{array}{l}\text { Classrooms used for } \\
\text { Didactics and Teaching } \\
\text { Practices }\end{array}$ & 44.1 & 13.0 & 23.4 & 19.4 & 42.8 \\
\hline
\end{tabular}

*Space for pedagogy training, educational sciences, research in education, philosophy and psychology. Source: Authors' elaboration.

Data from Table 7 reveal that $42.5 \%$ of the students state that teachers from field-specific subjects have never asked them to used Ceibal devices in their classes. 50.7\% expressed that none of the educational sciences teachers (pedagogy, psychology, research in education) had asked them to do so, and what it is all the more remarkable is that $44.1 \%$ of the students expresses that their didactics teachers did not ask for the use of the technological tool for classroom work as a support for their learning. An indicator was built to measure the frequency of use in the three training facilities (sum of at least once a week plus in every class). In all cases, values are under $50 \%$ of the students that actually incorporate technology in their classes.

Regarding values related to the use of the devices in their practices, 33\% expresses that they have almost never, or never used them, value that is under the percentages obtained with regard to the use of devices in the teacher training classes. From these data, it is possible to conclude that there is more use in the teaching practices than in the different subjects from the teacher training degree.

In light of this reality, it is interesting to wonder whether having the device means that future teachers include them in their teaching practices: is there any relation between having a laptop and its use in the pre-professional facility by the trainees in the institutions of secondary education? The Pearson's test based on the collected evidence generated a p - value and an . Consequently, is accepted and it can be said that variables are independent with a 95\% degree of reliability. This finding confirms what several studies state (OECD, 2015; PEDRÓ, 2014; HARGITTAI; HSIEH, 2013): providing this type of technology is not enough for teachers to decide to incorporate them in their practices as pedagogical tools.

The little use of personal laptops in the teacher training degree becomes evident both from the data from the survey as well as from what was expressed by the different actors of the interviews. In that regard, one of the interviewed managers commented on the less frequent use given to the laptop in the teacher training degree in comparison to the teaching practices: 
[...] in practice I have seen experiences... but it is a different thing to work with technology in the classrooms of the teacher training degree. That, I do not see. It is not a frequent use, beyond what can be done in terms of searching for information [.....$^{4}$

In keeping with what was expressed, Didactics teachers from both modalities (face-to-face and blended learning) express that there are students in their last year that do not show competencies in terms of handling educational technologies. This aspect may be directly linked to the fact that there is not a generalised work in the teacher training degree that involves the delivered mobile devices.

I believe that there is yet much to be done. I receive students in Didactics III and, therefore, it is assumed that they already have some ground covered in terms of teacher training; it would be expected for them to have an important relationship with technology, using it for their own learning and to encourage it among their own students. It is not like this. (PDBSP)

[...] a man over 40 years old from Juan Lacaze, that is about to finish his teacher training degree [...], uploaded to the platform a picture of the first page of the Planning because the program did not allowed him to upload so many pictures. (PDMSP)

Another relevant aspect refers to the fact that not only there are differences in the frequency of use of laptops but also in how they are used in different contexts. The use of laptops in practice involves, for instance, a wider range of tools as opposed to what happens in the teacher training degree, which becomes evident in what the didactics teachers expressed in the following quotations:

I believe that in the teacher training degree, what is done is quite at a basic level... the screen is still being used for projecting on a larger scale. (PDQSP)

A wider range of tools is used in the practices than in the teacher training degree, with a few exceptions. At secondary level, there is a wider exploration of tools and applications. (PDBSP) 
Even when there is not a systematic approach of the use of the device in the teacher training degree, many students decide to incorporate it in their practices. $32 \%$ of them say they use it once a week, and $19 \%$ of them at least once a month, which may be linked to at least two factors.

On the one hand, it may be related to the fact that students consider that the use of these devices has changed their way of learning, and, on the other hand, to the fact that they receive their didactic teachers' suggestions about including them in their secondary education classes.

With regard to the former aspect, high percentages were noted in relation to a positive vision of student teachers towards the use of technology in general (85\%) and, despite it is sensibly lower, there is an important number of respondents that perceive that the laptops delivered by Ceibal have impacted in their learning (54\%).

From these data, the following work hypothesis arises: is there a relation between the respondents' self-perception of the impact of laptops over the learning process and their inclusion of the device in their teaching practices? The Pearson's test, based on the collected information, generated a $\mathrm{p}$ and with 3df. for . Results allow us to reject the null hypothesis and affirm that variables are related with a 95\% degree of reliability: the positive self-perception influences the incorporation of the device. Alternatively, in other words, the appreciation of the positive impact that the device may have in the learning process leads them to decide accepting the challenge of using it in their teaching practices.

The other identified key aspect was to know whether there is a statistical relation between the didactics teachers' request to trainees to include laptops in their classroom proposals and the impact this initiative has over the frequency of use that the future teachers manifest.

The Pearson's test, based on the collected information, generated a $\mathrm{p}$ with an for . Results allow us to reject the null hypothesis and confirm that variables are related with a 95\% degree of reliability.

It is possible to affirm, consequently, that there is another factor that influences the inclusion of mobile devices delivered to the students in the secondary education classes. This is the suggestions they receive from their teachers, who guide them in the task of learning to teach.

These results allow us to assume that the didactics teachers' guidance about the use of laptops is related to the fact that the trainees take them to secondary education classes. In this regard, it is interesting to analyse from the conducted interviews, how teachers and students perceive the given recommendations, what type of guidance is given to the trainees and in which cases this orientation is requested or claimed by the students.

Table 8 includes evidence that allows us to know the characteristics of the guidance, how teachers identify the need of offering such orientation and examples of concrete actions that were implemented. The table discriminates also the training modality from the teachers that made the comments. 


\begin{tabular}{|c|c|c|c|}
\hline \multirow{2}{*}{$\begin{array}{l}\text { TRAINING } \\
\text { MODALITY }\end{array}$} & \multicolumn{3}{|c|}{ GUIDANCE GIVEN BY THE TEACHERS } \\
\hline & $\begin{array}{l}\text { CHARACTERISTICS } \\
\text { OF THE GUIDANCE }\end{array}$ & $\begin{array}{l}\text { IDENTIFICATION } \\
\text { OF THEIR NEED }\end{array}$ & $\begin{array}{l}\text { EXAMPLES OF GIVEN } \\
\text { GUIDANCE }\end{array}$ \\
\hline Face-to-face & $\begin{array}{l}\text { It needs to be something } \\
\text { that really helps me in } \\
\text { life, mind-opener and not } \\
\text { limited to something too } \\
\text { specific }[\ldots] \text {... }\end{array}$ & $\begin{array}{l}\text { I think that that is done, } \\
\text { and it needs to be done, } \\
\text { undoubtedly. [...] Teachers } \\
\text { need to feel confident about } \\
\text { what they are doing. They } \\
\text { need to feel free... and not } \\
\text { scared about the resource } \\
\text { they are using. }\end{array}$ & $\begin{array}{l}\text { If they do not have internet } \\
\text { access in the classroom, let it } \\
\text { be a work tool for the outside. } \\
\text { Technology should not be } \\
\text { disregarded because of the } \\
\text { obstacles that one faces when } \\
\text { trying to use it. }\end{array}$ \\
\hline $\begin{array}{l}\text { Blended } \\
\text { Learning }\end{array}$ & $\begin{array}{l}\text { We didactics' teachers } \\
\text { have been changing the } \\
\text { syllabi, or at least we have } \\
\text { been trying to incorporate } \\
\text { the new technologies... } \\
\text { we have been training } \\
\text { ourselves in that matter to } \\
\text { know how to respond to } \\
\text { the need. }\end{array}$ & $\begin{array}{l}\text { A novice teacher needs } \\
\text { guidance [...]; they usually get } \\
\text { a bit confused in the use of } \\
\text { the informatics tool because } \\
\text { they are not used to it. }\end{array}$ & $\begin{array}{l}\text { Specific guidance, for example, } \\
\text { regarding the didactics } \\
\text { sequence and the organisation } \\
\text { of the thinking, when mobile } \\
\text { devices are included in the } \\
\text { lesson plans. }\end{array}$ \\
\hline
\end{tabular}

Source: Authors' elaboration.

According to what was expressed in the interviews, there is also evidence that confirms that it is students who request guidance from their didactics' teachers:

Obviously, when I mentioned the possibility of doing the blog [...] she encouraged me (the didactics' teacher), she stimulated me, suggested that I should search in certain places in order to improve the blog, I felt quite supported in that sense. (EBSP)

Since they work in the Platform, in the end it leads to: "well, I do not know how to do it, but I need to learn how to do it". They then look for help from a classmate or a teacher that explains it to them. (EMSP)

Another interesting aspect related to the guidance is those allusions that underline the importance of self-learning regarding what digital technology offers. In some cases, teachers and students identify that their learnings have been without formal guidance as opposed to what they call "self-taught”, aspect that can be appreciated in the following fragments:

[...] I had already started using them on my own. I use it OK, but not because / have received guidance. (EMSP) 
EQpres. [...] one can be an autodidact and investigate but it is great that this is encouraged. There are many tutorials; therefore, one can be an autodidact. (PDDSP)

Along the same lines, some teachers point out that the given guidance must, in a way, prepare future teachers for the permanent change inherent to technology, by offering general guidance such as familiarising with tutorials as a strategy to favour self-training.

Both in the blended and in the face-to-face modality, I suggest them certain programs and I then ask them to look for their tutorials. Given that information is so dynamic, they cannot depend on somebody bringing it to them; they must learn to manage information and to select it according to what is needed. (PDQP)

The concept of best practices proposed by De Pablos and Jiménez (2007) will be the reference framework used to analyse the answers given to two of the questions that we asked to the interviewees: what characteristics must a best practice in education have that incorporates technology and mobile devices? And, what examples of best practices have you had or applied?

The received answers for both questions were succinct and too general. The didactic characterisation of the activity that involved ICT was poorly explored. This even happened coming from the didactics' teachers.

From the reading of the evidence gathered in Graph 1, it is possible to appreciate the aspects that are considered signs of best practices. These refer especially to the technical control of the technological resource, to assigning it a recreational use and to catering for aesthetic aspects. According to the consulted teachers, best practices in education must use technology at the service of the student learning; the proposed activities must be coherent with the rest of the elements of the didactics planning and must contribute to the training of the students (learning to learn). 
"We could say "there is too much preparatory work", but it is exactly that which goes beyond the planning... it needs to be immersed in the content to be taught, with the difficulty of solving the technological aspects." (GIT)

"First, the teacher needs to know how to use the mobile device. Secondly, the topic for which it is going to be used needs to be clear. It is necessary to be clear about the activity for approaching that topic, using a certain application." (EHP)

"Coping with the unexpected, if internet connection fails you need to adapt; before, there were fewer unexpected events." (EMSP)

"To be clear when it comes to giving information, to be not recreational. It happened to me with the blog that I changed the format many times, the colour, because what was not messy for me, it was for them. I had to be visually clear, simple, the colours had to be visible, not too far-fetched because they would get discouraged and leave"

"Best practices are not deduced by the use of technology. That is the first thing to be mentioned. Best practices are defined because the teacher is permanently centred in the students' learning." (PDBSP)

"That the didactics sequence is appropriate; that everything is aligned: the objectives, the strategies and the assessment." (PDBSP)

"The assessment needs to change: it must be consistent with the innovation. If knowledge wants to be visualised in a different way, one cannot turn to the traditional methods when it comes to assessing" (PDQSP)

"To know how to prepare them for the positive and negative value of being able to use them. One has the tool and at the same time, a weapon" (PDDSP)

"It needs to be something that really helps me in life, mind-opener and not limited to something too specific, an algorithm to solve something. That helps me to relate with another person, that helps me to do an intelligent search".(PDQP)

Source: Authors' elaboration.

The examples given involve the incorporation of ICT to look for information online, to sign in into virtual and online science labs, to do digital portfolios, to use sensors for physicochemical variables, to organise the course in virtual online desks, to calculate and do other math exercises, to create some kind of virtual classroom, to take pictures.

With reference to the examples of best practices that involved the use of ICT, Graph 2 presents extracts from the revealed answers. 


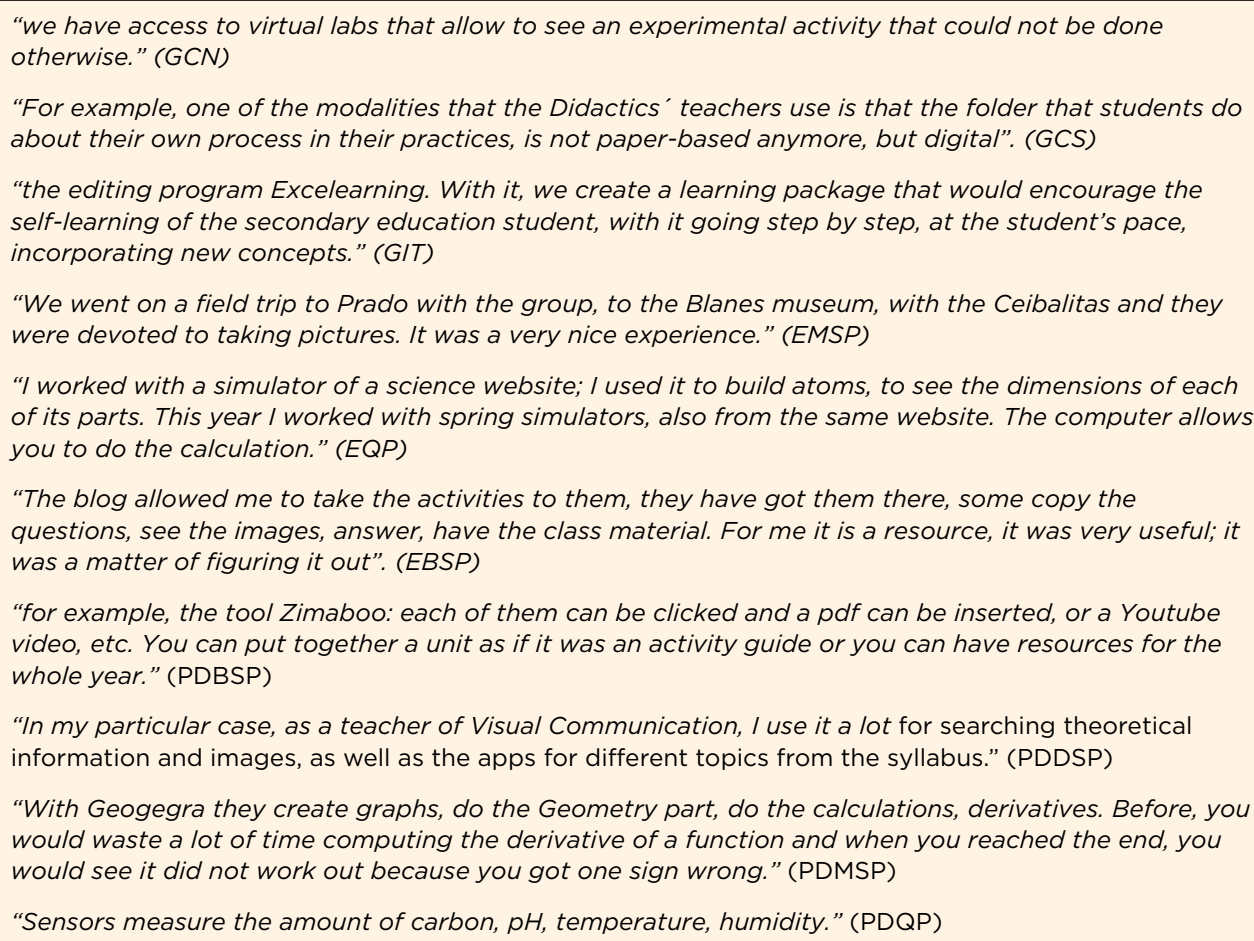

Source: Authors' elaboration.

In keeping with the aforementioned concept of best practices (DE PABLOS; JIMÉNEZ, 2007; CABERO, 2008), from the overall analysis of the two questions asked to the interviewees, one can identify the coexistence of technological visions rather than didactics-related ones about the use of educational technologies.

On the one hand, it is clear that the development of competencies for using the different online resources (for example, virtual science labs, virtual desks, search engines), as well as installed software (for instance, OpenOffice, Geogebra), requires teachers to acquire new knowledge about the tools functionality and digital resources in the teaching of their subject matter.

However, apart from the technological abilities, it is necessary to acquire and develop pedagogical competencies in the use of ICT that enhance them in the collective construction of knowledge and in the development of cognitive processes. In the analysed discourses, it is possible to establish the importance that teachers place in the benefits on the learning process that arise from the interaction and exchange between trainees and teachers. Also, the importance of developing abilities for the process of learning to learn through collaborative experiences.

The analysed qualitative data are consistent with what Maggio (2014) states, in the sense that teachers must overcome the idea of ICT as mere technical/ functional instruments and understand that educational technologies support new ways of producing and circulating knowledge. The didactics proposals 
need to create and foster new digital and flexible learning contexts through new models for incorporating ICT both inside and outside the classroom, and in face-to-face and virtual training modalities.

\section{CONCLUSIONS}

The study carried out leads to various conclusions and findings that give account for the advances that have been made in terms of incorporating digital technology within the Plan Ceibal framework in Uruguay, and the pending challenges about the construction of new learning contexts based on digital tools.

It becomes evident that the speed of the technological changes and the expansion of the technology through ICT policies at a national scale does not match the changes in the practices and teacher training. Thus, the trainer of trainers' practices are far from being at the forefront (CASTANEDD; ESTEVE; ADELL, 2018). The challenge for these kind of policies will mean, on one end, to have effectively working devices delivered to teachers and students and, on the other end, to carry out actions that allow these teachers to be trained in how to take advantage of the technological resources in the interest of a transformation of the learning processes.

According to the findings of this study, students do not identify the teacher training degree as a favourable context for digital technologies to be leveraged from a pedagogical perspective, which limits the opportunities to achieve new ways of teaching and learning (COBO, 2016). In keeping with what the future teachers expressed, their trainers in the different fields of knowledge (educational sciences, didactics, and subjects specific from the chosen degree) are far from being "catalysts" in their learnings regarding the incorporation of Technologies (CASTAÑEDA; ESTEVE; ADELL, 2018). The use of laptops in teacher training classes is scarce, plus, there is still no evidence that when they are indeed incorporated, it is done considering the development of pedagogical competencies, which may be due to the lack of ICT competencies development in many trainers (ASLAN; ZHU, 2015; KALONDE; MOUSA, 2016, AESAERT; TONDEUR; SIDDIQ, 2018).

The scarce development of competencies in trainers and future teachers is directly related to the training they have received regarding the advantage that technologies offer to improve their practices. According to what the INEED (2017) expressed, the teachers' requests for training is not exclusive from Uruguay, since it has been identified in international reports as well, such as OECD $(2013,2015)$.

The training of trainers is especially important in training facilities that are in charge of didactics guidance and teaching practices. Even though laptops are not frequently used in the teacher training degree, future teachers are more receptive to incorporating them in their practices when the Didactics teachers ask them to do so. The data gathered reveal the paradox that many students have not managed to sufficiently develop the competencies that allow them to take advantage of technologies in the classroom as students, but they need to face the challenge of incorporating them in their teaching practices. 
We consider there are two factors that act as obstacles for innovation. On the one hand, the poor training of trainers and, on the other one, the confirmation that there is not enough critical reflexion about how to use technologies to "catalyse" learnings. Because of this, in most of the analysed cases, the teaching proposals are focused more on the technology than in the new pedagogies (FERGUSON; BUCKINGHAM, 2012; FULLAN; QUINN, 2017; MCKINSEY, 2017).

Nevertheless, what also arises from the data gathered is there are experiences that seek to position teaching from a perspective that locate the student in a preferential place as manager of his or her own learning. The key of these "best practices" seems to be in the development of metacognitive skills (COBO, 2016) on the part of the didactics teachers and what they encourage in the future teachers. Fostering self-learning becomes key in a world where what is constant, is change.

In view of this, one may wonder about the characteristics that the training of trainers must have. Learning programs, applications and software may be important but it is not substantial given that what exists today, may not necessarily exist tomorrow (UNESCO, 2016a). It is for this reason that technological training is necessary, but in close liaison with the teachers' pedagogical training (VAILLANT, 2013). The aforementioned coincides with what UNESCO (2016a, p. 141) proposes when it states that it is essential to "further strengthen teachers concerning the necessary knowledge to guide new pedagogical processes with the integration of ICT". ${ }^{5}$

Not only more technological training is needed, but also the transformation of practices requires to be supported by constant pedagogical reflexion. The guidance and practices promoted in the teacher training degree and especially from the didactics perspective should not be limited only to classical didactics questions: "what and how to teach". In contrast, they should shift towards the learning, answering the question of why we are teaching and how we create learning environments in contexts of high availability of technology of teachers and students.

As challenges for future studies, it is necessary to explore different aspects related to the teacher training degree. On one hand, research should focus on understanding how it may become a context where the incorporation of digital technologies favours the learning. Besides, research should explore how it can lead processes of pedagogical reflexions that become driving forces to transform teaching practices both in the training of future teachers as well as in the continuing professional development of active teachers for it to positively influence secondary education practices.

5 In original: "profundizar el fortalecimiento de los docentes en lo relativo a los conocimientos necesarios para conducir nuevos procesos pedagógicos con integración TIC". 
ADELL, Jordi; CASTAÑEDA, Linda. Tecnologías emergentes, ¿pedagogías emergentes? In: Hernández, J.; Pennesi, M.; Sobrino, D.; Vázquez, A. (coord.). Tendencias emergentes en educación con TIC. Barcelona: Asociación Espiral, Educación y Tecnología, 2012. p. 13-32.

AESAERT, Koen; TONDEUR, Jo; SIDDIQ, Fazilat. Pre-service teachers' technology competences: do teacher training strategies matter?. Conference: American Educational Research Association (AERA) 2018. At New York (US). Projects-Preparing future teachers for ICT integration in education. April 2018.

ALEXANDER, Robin. Policy and practice in primary education: local initiative, national agenda. Abingdon: Routledge, 1997.

ASLAN, Aydm; ZHU, Chang. Pre-Service Teachers' Perceptions of ICT Integration in Teacher Education in Turkey. TOJET: The Turkish Online Journal of Educational Technology, v. 14, n. 3, p. 97-110, 2015.

BAKIR, Nesrin. Technology and teacher education: a brief glimpse of the research and practice that have shaped the field. TechTrends, v. 60, n. 1, p. 21-29, 2016.

CABERO, Julio Almenara; ROMERO, Rosalía Tena. Análisis de buenas prácticas del e-learning en las universidades andaluzas. TESI, v. 11, n. 3, p. 283-309, 2010.

CASTAÑEDA, Linda; ESTEVE, Francesc; ADELL, Jordi. ¿Por qué es necesario repensar la competencia docente para el mundo digital? RED. Revista de Educación a Distancia, n. 56, p. 1-20, 2018.

CEIBAL Plan Ceibal, 10 años. 2007-1017. 2017. Disponible en: http://www.ceibal.edu.uy/storage/app/media/ documentos/ceibal-10-2.pdf. Acesso em: 5 mayo 2018.

COBO, Cristóbal. La innovación pendiente: reflexiones (y provocaciones) sobre educación, tecnología y conocimiento. Colección Fundación Ceibal/Debate: Montevideo, 2016.

CRESWELL, John; PLANO, Vicky Clarck. Designing and conducting mixed methods research. Thousand Oaks, CA: Sage, 2007.

DE PABLOS, Juan Pons; JIMÉNEZ, Rocío Cortés. Buenas prácticas con TIC apoyadas en las políticas educativas: claves conceptuales y derivaciones para la formación en competencias ECTS. Revista Latinoamericana de Tecnología Educativa, v. 6, n. 2, p. 15-28, 2007.

DE-MARCOS, Luis; HILERA, José; BARCHINO, Roberto; JIMÉNEZ, Lourdes; MARTÍNEZ, José; GUTIÉRREZ, José; OTÓN; Salvador. An experiment for improving students performance in secondary and tertiary education by means of m-learning auto-assessment. Computers y Education, v. 55, n. 3, p. 1069-1079, 2010.

DENZIN, Norman; LINCOLN, Yvonna. The Sage handbook of qualitative research. 3. ed. Thousand Oaks: Sage, 2005.

DÍAZ DE RADA, Vidal. Ventajas e inconvenientes de la encuesta por internet. Papers. Revista de Sociología, v. 97 , n. 1, p. 193-223, 2012.

DONOVAN, Loretta; GREEN, Tim; HANSEN, Laurie. One-to-One Laptop Teacher Education. Journal of Research on Technology in Education, v. 44, n. 2, p. 121-139, 2011.

FERGUSON, Rebecca; BUCKINGHAM, Simon. Social learning analytics: five approaches. Proceedings International Conference on Learning Analytics \& Knowledge, 2. 2012 (29 Apr-2 May, Vancouver, BC). ACM Press: New York, 2012. Disponible en: http://projects.kmi.open.ac.uk/hyperdiscourse/docs/LAK2012-RF-SBS. pdf. Acesso em: 5 mayo 2018.

FULLAN, Michael; QUINN, Joanne. Coherencia: los impulsores correctos en acción para escuelas, distritos y sistemas. Montevideo, Red Global de Aprendizajes, Ceibal, 2017.

GALPERÍN, Hernán. Digital Society: Gaps and Challenges for Digital Inclusion in Latin America and the Caribbean. Published in 2017 by the United Nations Educational, Scientific and Cultural Organization UNESCO and the Regional Bureau for Sciences in Latin America and the Caribbean, UNESCO Montevideo, 2017. 
GLASER, Barnen; STRAUSS, Anselm. El muestreo teórico. En: Glaser, B.; Strauss, A. The Discovery, of grounded theory: strategies for qualitative research. New York: Aldine Publishing Company, 1967.

HARGITTAI, Eszter; HSIEH, Yuli Patrick. Digital inequality. In: Dutton, W. H. (ed.). The Oxford Handbook of Internet Studies. Oxford, UK: Oxford University Press, 2013.

HEERWEGH, Dirk; LOOSVELDT, Geert. Face-to-face versus web surveying in a high-internet- coverage population: differences in response quality. Public Opinion Quarterly, v. 72, n. 5, p. 836-846, 2008.

HINOSTROZA, Enrique. ICT, education and social development in Latin America and the Caribbean. Published in 2017 by the United Nations Educational, Scientific and Cultural Organization - UNESCO and the Regional Bureau for Sciences in Latin America and the Caribbean, UNESCO Montevideo. 2017.

HOLMBERG, Anders; LORENC, Boris; WERNER, Peter. Contact strategies to improve participation via the Web in a Mixed-Mode Mail and Web Survey. Journal of Official Statistics, v. 26, n. 3, p. 465-480, 2010.

HUTCHISON, Amy; REINKING, David. Teachers' perceptions of integrating information and communication technologies into literacy instruction: A National Survey in the United States. Reading Research Quarterly, v. 46, n. 4, p. 312-333, 2011.

INSTITUTO NACIONAL DE EVALUACIÓN EDUCATIVA, Informe de la Encuesta Nacional Docente 2015. Montevideo: INEED, 2017.

JISU, Huh; DELORME, Denise; REID, Leonard. Perceived third-person effects and consumer attitudes on prevetting and banning DTC advesiting. Journal of Consumer Affairs, v. 40, n. 1, p. 90-116, 2006.

KALONDE, Gilbert; MOUSA, Rabab. Technology familiarization to preservice teachers: factors that influence teacher educators' technology decisions. Journal of Educational Technology Systems, v. 45, n. 2, p. 236-255, 2016.

MAGGIO, Mariana; LION, Carina; PEROSI, María. Las prácticas de la enseñanza recreadas en los escenarios de alta disposición tecnológica. Polifonías Revista de Educación, Año III, n. 5, p. 101-127, 2014.

MARCELO, Carlos, YOT, Carmen; MAYOR, Cristina. "Alacena”: repositorio de diseños de aprendizaje para la enseñanza universitaria. Comunicar, v. 19, n. 37, p. 37-44, 2011.

MAXWELL, John. Qualitative research design: an interactive approach. Londres: Sage, 1996.

MCKINSEY. Informe elaborado por Alberto Chaia, Andrés Cadena, Felipe Child, Emma Dorn, Marc Krawitz y Mona Mourshed. Factores que inciden en el desempeño de los estudiantes: perspectivas de América Latina. Educación, Sep 2017. Disponible en: https://www.mckinsey.com/ /media/mckinsey/industries/ social\%20sector/our\%20insights/what\%20drives\%20student\%20performance\%20in\%20latin\%20america/ factores-que-inciden.ashx. Acesso em: 5 mayo 2018.

MILES, Mattheu; HUBERMAN, Michael. Qualitative data analysis: a sourcebook of new methods. Sage, 1984.

OECD. Innovative learning environments: educational research and innovation. Paris: OECD, 2013.

OECD. Students, computers and learning: making the connection. Paris: OECD. 2015. Disponible en: http://www.mecd.gob.es/dctm/inee/internacional/pisa-2012-students-computers.pdf?documentId=0901e72b 81e9cc75. Acesso em: 5 mayo 2018.

PEDRÓ, Francesco. Tecnologías para la transformación de la educación: experiencias de éxito y expectativas de futuro. XXIX Semana de la Educación, Madrid, España, 2014.

RODRIGUEZ, Eduardo; MARCELO, Carlos; BERNASCONI, Gabriela; YOT, Carmen; TELIZ, Fabián; UMPIERREZ, Silvia. Educadores en la era digital: aprender a enseñar con tecnologías en la formación inicial de profesores de educación media en Uruguay. Montevideo, Uruguay, 2017. Disponible en: https://igital. fundacionceibal.edu.uy/jspui/handle/123456789/222. Acesso em: 5 mayo 2018.

SALEH, Slah Al; BHAT, Sammer Almad. Mobile Learning: A Systematic Review. International Journal of Computer Applications, v. 114, n. 11, p. 1-5, 2015. 
SIPILÄ, Keijo. The impact of laptop provision on teacher attitudes towards ICT. Technology, Pedagogy and Education, v. 19, n. 1, p. 3-16, 2010.

STRAUSS, Anselm; CORBIN, Juliet; ZIMMERMAN, Eva. Bases de la investigación cualitativa: técnicas y procedimientos para desarrollar la teoría fundamentada. Medellín: Universidad de Antioquia, 2002.

UNESCO. Revisión comparativa de iniciativas nacionales de aprendizaje móvil en América Latina: el caso del Plan Ceibal de Uruguay. Buenos aires: UNESCO, 2016a.

UNESCO. Revisión comparativa de iniciativas nacionales de aprendizaje móvil en América Latina: los casos de Colombia, Costa Rica, Perú y Uruguay. IIPE Buenos Aires. UNESCO, 2016 b.

UNESCO. E2030: education and skills for the 21st century. In: REGIONAL MEETING OF MINISTERS OF EDUCATION OF LATIN AMERICA AND THE CARIBBEAN. Buenos Aires, Argentina, January 24-25, UNESCO, 2017.

VAILLANT, Denise. Integración de TIC en los sistemas de formación docente inicial y continua para la educación básica en América Latina. Buenos Aires, Argentina: UNICEF, 2013.

VAILLANT, Denise; RODRIGUEZ, Eduardo; BERNASCONI, Gabriela. Modalidad MOOC para educación media básica: enseñanzas de una experiencia. Perfiles Educativos, v. 39, n. 156, p. 103-118, 2017.

WITECKI, Gwendolyn; NONNECKE, Blair. Engagement in digital lecture halls: A study of student course engagement and mobile device use during lecture. Journal of Information Technology Education: Research, v. 14, p. 73-90, 2015.

NOTE: The authors declare equity in the process of developing the article. The authors E.R.Z., C.Y., C.C., J.P.Z.S., participated in equal conditions in the elaboration of the methodological design, construction of the theoretical framework and discussion of results. J.G.S. collaborated in the qualitative analysis of the results and in the discussion of the conclusions.

\section{HOW TO CITE THIS ARTICLE:}

RODRÍGUEZ ZIDÁN, Eduardo; YOT, Carmen; CABRERA, Claudia; ZORRILLA SALGADOR, Juan Pablo;

GRILLI SILVA, Javier. Challenges for the design of new pedagogies based on mobile technologies. Cadernos de Pesquisa, São Paulo, v. 49, n. 172, p. 236-259, abr./jun. 2019. https://doi.org/10.1590/198053145513 